\title{
PENGARUH RISIKO SISTEMATIS TERHADAP KINERJA PERUSAHAAN DAN IMPLIKASINYA PADA NILAI PERUSAHAAN \\ (Studi Pada Perusahaan Food and Beverage di Bursa Efek Indonesia Tahun 2007-2011)
}

\author{
Erik Syawal Alghifari \\ Mahasiswa Magister Manajemen Bisnis \\ Sekolah Pasca Sarjana Universitas Pendidikan Indonesia
}

\begin{abstract}
Abstrak
Penelitian ini bertujuan untuk mengetahui 1) Gambaran risiko sistematis 2) Gambaran kinerja perusahaan 3) Gambaran nilai perusahaan 4) Pengaruh risiko sistematis terhadap kinerja perusahaan 5) Pengaruh kinerja perusahaan terhadap nilai perusahaan 6) Pengaruh risiko sistematis terhadap nilai perusahaan. Teknik pengambilan sampel menggunakan metode teknik sampling purposive. Teknik pengumpulan data menggunakan teknik dokumentasi dengan data sekunder. Metode analisis data yang digunakan meliputi statistik deskriptif dan analisis jalur. Hasil penelitian menunjukkan 1) Rata-rata beta agresif (nilai 8 lebih besar dari satu) terjadi pada tahun 2010 dan tahun 2011, ratarata beta defensif (nilai $B$ lebih kecil dari satu) terjadi pada tahun 2007, tahun 2008 dan tahun 2009 2) Rata-rata ROA positif terjadi pada tahun 2009, tahun 2010 dan tahun 2011, rata-rata ROA negatif terjadi pada tahun 2007 dan tahun 2008 3) Rata-rata nilai perusahaan tahun 2007-2011 memiliki rasio a atau Tobin's $Q$ diatas satu 4) Tidak terdapat pengaruh risiko sistematis terhadap kinerja perusahaan 5) Terdapat pengaruh kinerja perusahaan terhadap nilai perusahaan 6) Terdapat pengaruh risiko sistematis terhadap nilai perusahaan.
\end{abstract}

Kata Kunci: Risiko Sistematis (B), Kinerja Perusahaan (ROA), Nilai Perusahaan (Tobin's Q)

\section{PENDAHULUAN}

Lingkungan bisnis yang kompetitif menyebabkan perusahaan harus berjuang agar perusahaannya bisa bertahan. Perusahaan berinovasi, membeli teknologi baru, melakukan pengembangan produk bahkan melakukan perluasan wilayah usaha dalam menghadapinya, usaha yang dilakukan perusahaan itu membutuhkan biaya yang tidak sedikit. Pasar modal merupakan alternatif pendanaan bagi perusahaan sehingga perusahaan dapat beroperasi dengan skala yang lebih besar dan pada akhirnya meningkatkan profit.

Perkembangan pasar modal di Indonesia perlahan maju selama beberapa tahun, hal ini dapat dilihat dari nilai kapitalisasi dan Indeks Harga Saham Gabungan (IHSG) setiap tahunnya. Kenaikan kapitalisasi pasar terjadi pada tahun 2006 sampai 2007 dan tahun 2008 sampai 2011, tetapi terjadi penurunan nilai kapitalisasi pasar yang cukup besar tahun 2007 sebesar $\mathrm{Rp}$ 1.988.326,20 miliar menjadi Rp 1.076.490,53 miliar pada tahun 2008. Indeks harga saham gabungan (IHSG) mengalami mengalami penurunan pada tahun 2008 perubahannya sebesar $(1.390,42)$, penurunan nilai kapitalisasi pasar dan IHSG disebabkan oleh gejolak krisis keuangan global.

Gejolak krisis keuangan yang terjadi pada pasar modal tahun 2008 tersebut ternyata mempengaruhi berbagai sektor industri yang ada di Indonesia termasuk perusahaan manufaktur. Perusahaan manufaktur merupakan salah satu sektor yang diklasifikasikan di Bursa Efek Indonesia (BEI). Salah satu jenis perusahaan manufaktur yang termasuk ke dalamnya adalah industri barang konsumsi (consumer goods industry). Industri ini merupakan industri yang tujuannya menghasilkan bermacam-macam 
barang kebutuhan konsumsi. Industri barang konsumsi ini terbagi menjadi beberapa klasifikasi, diantaranya: tobacco manufacturer, food and beverage, pharmaceuticals, houseware, cosmetics and household. Dari beberapa klasifikasi tersebut, penulis tertarik pada perusahaan food and beverage dengan alasan industri makanan dan minuman ini mengalami peningkatan yang cukup pesat, dilihat dari Badan Pusat Statistik (BPS) dari situs resminya www.bps.go.id terjadi peningkatan produksi pada industri ini di tahun 2010 sebesar 6,41 (satuan 2 digit kode International Standard Industrial Classification) menjadi 8,34 (satuan 2 digit kode International Standard Industrial Classification) di tahun 2011, berkembang pesatnya industri makanan dan minuman ini sangat ditunjang populasi penduduk Indonesia besar. Penurunan nilai kapitalisasi terjadi pada tahun 2007 sebesar Rp 36.397 miliar menjadi Rp 17.106 pada tahun 2008, setelah itu tahun 20082011 terjadi kenaikan. Berbeda dengan rata-rata harga saham perusahaan food and beverage terjadi peningkatan dari tahun 2007-2010, tetapi terjadi penurunan di tahun 2010 sebesar Rp 44.539 menjadi Rp 35.900, hal ini menunjukan bahwa nilai kapitalisasi pasar perusahaan food and beverage terpengaruh oleh dampak krisis keuangan global sedangkan rata-rata harga saham perusahaan food and beverage tidak terpengaruh dampak krisis keuangan global, tetapi pada tahun 2011 rata-rata harga saham mengalami penurunan ini bisa disebabkan oleh krisis ekonomi Eropa. Berdasarkan kondisi ini dan kondisi lainnya, perusahaan-perusahaan yang tergolong food and beverage mengalami perubahan setiap tahunnya, ada yang delisting dan ada juga yang listing, tetapi ada beberapa perusahaan yang masih bertahan. Pada tahun 2007 perusahaan food and beverage berjumlah 15 perusahaan, tahun 2008 berkurang menjadi 14 perusahaan, tahun 2009 berkurang menjadi 13 perusahaan, tahun 2010 bertambah menjadi 15 perusahaan dan pada tahun 2011 berkurang menjadi 14 perusahaan. Oleh karena itu, pengamatan empirik pada penelitian ini berdasarkan purposive sampling, pengamatan dilakukan terhadap 12 perusahaan food and beverage yang terdaftar di BEI.

Saham menjadi salah satu alternatif investasi di pasar modal yang paling banyak digunakan oleh para investor karena keuntungan yang diperoleh lebih besar dan dana yang dibutuhkan investor untuk melakukan investasi tidak begitu besar jika dibandingkan dengan obligasi. Tujuan perusahaan melakukan investasi saham adalah untuk memaksimalkan kesejahteraan pemegang saham dengan cara memaksimalkan nilai saham perusahaan yang pada akhirnya akan mencerminkan harga saham tersebut. Nilai perusahaan merupakan harga yang bersedia dibayar oleh calon pembeli andai perusahaan tersebut di jual (Suad Husnan dan Enny Pudjiastuti, 2004:6), salah satu pertimbangan investor sebelum menentukan nilai dari suatu perusahaan adalah potensi dan pertumbuhan perusahaan di masa yang akan datang, semakin tinggi nilai perusahaan akan semakin besar kemakmuran yang akan diterima oleh pemegang saham. Berdasarkan penjelasan tersebut, maka nilai perusahaan sangat penting sekali bagi suatu peusahaan. Berdasarkan beberapa penelitian terdahulu yang dilakukan oleh Bambang Sudiyatno (2010), Uchida (2006), Villalonga \& Amit (2004), nilai perusahaan diukur menggunakan Tobin's $Q$ atau q ratio, gambaran kenaikan dan penurunan nilai perusahaan pada 12 perusahaan food and beverage yang terdaftar di BEI tahun 2007-2011 adalah sebagai berikut : penurunan nilai kapitalisasi pada tahun 2007 sebesar Rp 36.397 miliar menjadi Rp 17.106 pada tahun 2008, setelah itu tahun 2008-2011 terjadi kenaikan. Berbeda dengan rata-rata harga saham perusahaan food and beverage terjadi peningkatan dari tahun 2007-2010, tetapi terjadi penurunan di tahun 2010 sebesar Rp 44.539 menjadi Rp 35.900, hal ini menunjukan bahwa nilai kapitalisasi pasar perusahaan food and beverage terpengaruh oleh dampak krisis keuangan global sedangkan rata-rata harga 
saham perusahaan food and beverage tidak terpengaruh dampak krisis keuangan global, tetapi pada tahun 2011 rata-rata harga saham mengalami penurunan ini bisa disebabkan oleh krisis ekonomi Eropa. Berdasarkan kondisi ini dan kondisi lainnya, perusahaan-perusahaan yang tergolong food and beverage mengalami perubahan setiap tahunnya, ada yang delisting dan ada juga yang listing, tetapi ada beberapa perusahaan yang masih bertahan. Pada tahun 2007 perusahaan food and beverage berjumlah 15 perusahaan, tahun 2008 berkurang menjadi 14 perusahaan, tahun 2009 berkurang menjadi 13 perusahaan, tahun 2010 bertambah menjadi 15 perusahaan dan pada tahun 2011 berkurang menjadi 14 perusahaan. Oleh karena itu, pengamatan empirik pada penelitian ini berdasarkan purposive sampling, pengamatan dilakukan terhadap 12 perusahaan food and beverage yang terdaftar di BEI.

Saham menjadi salah satu alternatif investasi di pasar modal yang paling banyak digunakan oleh para investor karena keuntungan yang diperoleh lebih besar dan dana yang dibutuhkan investor untuk melakukan investasi tidak begitu besar jika dibandingkan dengan obligasi. Tujuan perusahaan melakukan investasi saham adalah untuk memaksimalkan kesejahteraan pemegang saham dengan cara memaksimalkan nilai saham perusahaan yang pada akhirnya akan mencerminkan harga saham tersebut. Nilai perusahaan merupakan harga yang bersedia dibayar oleh calon pembeli andai perusahaan tersebut di jual (Suad Husnan dan Enny Pudjiastuti, 2004:6), salah satu pertimbangan investor sebelum menentukan nilai dari suatu perusahaan adalah potensi dan pertumbuhan perusahaan di masa yang akan datang, semakin tinggi nilai perusahaan akan semakin besar kemakmuran yang akan diterima oleh pemegang saham. Berdasarkan penjelasan tersebut, maka nilai perusahaan sangat penting sekali bagi suatu peusahaan. Berdasarkan beberapa penelitian terdahulu yang dilakukan oleh Bambang Sudiyatno (2010), Uchida (2006),
Villalonga \& Amit (2004), nilai perusahaan diukur menggunakan Tobin's $Q$ atau q ratio, gambaran kenaikan dan penurunan nilai perusahaan pada 12 perusahaan food and beverage yang terdaftar di BEI tahun 2007-2011 adalah sebagai berikut: kenaikan rata-rata nilai perusahaan tahun 2007 sebesar 0,079 (satuan rasio), tahun 2009 sebesar 0,451(satuan rasio), tahun 2010 sebesar 0,219 (satuan rasio), tahun 2011 sebesar 0,011 (satuan rasio), sedangkan penurunan rata-rata nilai perusahaan tahun 2008 sebesar -0,203 (satuan rasio). Perusahaan-perusahaan yang tergolong perusahaan food and beverage nilai perusahannya juga mengalami kenaikan serta penurunan tiap tahunnya.

Nilai perusahaan pada perusahaan food and beverage berfluktuasi setiap tahunnya, ketidakstabilan nilai perusahaan sangat menyulitkan investor dalam melakukan investasi, oleh karena itu investor tidak sembarangan dalam melakukan investasi atas dana yang dimilikinya, nilai perusahaan ini bisa dipengaruhi oleh kinerja perusahaan. Kinerja perusahaan bagi investor adalah gambaran atau signal untuk memutuskan apakah investasi akan dilakukan, kinerja perusahaan yang baik akan menarik minat para investor untuk berinvestasi dengan membeli saham perusahaan melalui pasar modal, semakin tinggi kinerja perusahaan, semakin banyak investor yang tertarik untuk membeli saham perusahaan.

Pendekatan yang dapat digunakan untuk mengukur kinerja perusahaan berdasarkan kinerja keuangan perusahaan terdiri dari beberapa konsep, konsep ini telah banyak mengalami perkembangan, disamping konsepkonsep konvensional akuntansi yang tradisional seperti : ROE, ROA, EPS, Residual Income dan indikator-indikator kinerja yang lain, dari beberapa konsep tersebut ada yang dianggap mempunyai kemampuan yang lebih baik dalam mengukur kinerja perusahaan, yaitu Economic Value Added (EVA). Hasil penelitian yang dilakukan oleh Mike (1997) di Bursa Efek Jakarta dalam Bambang Sudiyatno (2010:14), 
menghasilkan kesimpulan bahwa hubungan Economic Value Added (EVA) dan Market Value Added (MVA) tidak signifikan. Artinya terjadi perbedaan antara apa yang dikemukakan oleh penggagas EVA (Stewart, 1995) dengan kenyataan yang terjadi di pasar modal Indonesia (BEI). Oleh karena itu, dalam penelitian ini pengukuran kinerja perusahaan menggunakan konsep konvensional akuntansi, yaitu ROA yang dianggap mempunyai kemampuan lebih baik dalam mengukur kinerja perusahaan, karena penelitian-penelitian sebelumnya menunjukan bahwa ROA dapat mereprensentasikan kepentingan stakeholders dan pengukuran kinerja lebih baik, seperti pada penelitian yang dilakukan oleh Akroman (2009), Dodd dan Chen (1996). Gambaran kinerja perusahaan pada 12 perusahaan food and beverage yang terdaftar di BEl tahun 2007-2011 adalah sebagai berikut : kenaikan rata-rata kinerja perusahaan terjadi pada tahun 2007 sebesar 9,491 (satuan rasio), tahun 2008 sebesar 0,038 (satuan rasio), tahun 2011 sebesar 0,886 (satuan rasio), sedangkan penurunan rata-rata kinerja perusahaan terjadi pada tahun 2009 sebesar -0,015 (satuan rasio) dan tahun 2010 sebesar -0,115 (satuan rasio). Perusahaan-perusahaan yang tergolong perusahaan food and beverage nilai perusahannya juga mengalami kenaikan serta penurunan tiap tahunnya.

Perusahaan-perusahaan yang tergolong perusahaan food and beverage kinerja perusahaannya juga mengalami kenaikan serta penurunan tiap tahunnya. Kinerja perusahaan food and beverage berfluktuasi setiap tahunnya, fluktuasi ini menyebabkan perusahaan dalam ketidakpastian, oleh karena kinerja perusahaan bisa dipengaruhi oleh risiko pasar atau risiko sistematis.

Perusahaan sebagai bagian dari suatu unit ekonomi akan menghadapi persoalan yang rumit apabila beroperasi pada tingkat risiko pasar yang tinggi, karena risiko pasar yang tinggi akan membuat kondisi bisnis menjadi tidak menentu atau dalam keadaan ketidakpastian. Penjualan perusahaan sulit diprediksikan secara tepat, sehingga perusahaan tidak dapat memprediksikan berapa laba yang akan diperolehnya Kondisi bisnis yang tidak menentu akan berpengaruh terhadap kinerja perusahaan, karena kinerja perusahaan sangat ditentukan oleh hasil penjualan pada setiap periodenya, sebaik apapun perusahaan dapat menghasilkan suatu produk namun jika tidak mampu menjual produk yang telah dihasilkannya, maka tidak akan ada artinya. Perusahaan akan banyak kehilangan kesempatan atau peluang untuk memperoleh laba, akibatnya terjadi sebaliknya karena perusahaan harus menanggung beban tetap yang tinggi sehingga dapat menurunkan kinerja perusahaan.

Risiko sistematis juga mempengaruhi nilai perusahaan, perusahaan dengan beta saham yang tinggi biasanya harga sahamnya sangat berfluktuasi, saham yang demikian tidak disukai oleh investor, akibatnya nilai transaksi dan volume perdagangannya akan menurun, menurunnya nilai transaksi dan volume perdagangan saham akan menurunkan indeks harga saham gabungannya. Penurunan indeks harga saham gabungan menggambarkan penurunan kinerja pasar modal, dengan menurunnya kinerja pasar modal, maka nilai perusahaan juga akan menurun.

Risiko sistematis (systematic risk) atau risiko pasar merupakan risiko yang ditimbulkan dari faktor-faktor fundamental makroekonomi; inflasi, tingkat bunga, kurs, dan pertumbuhan ekonomi (Jogiyanto, 2003:54), sebagai pengukur risiko sistematis (systematic risk) digunakan Beta ( $\beta$ ) pasar, yaitu Beta dari suatu sekuritas relatif terhadap risiko pasar. Penggunaan Beta pasar sebagai pengukur risiko dikarenakan bahwa Beta pasar mengukur respon dari masing-masing sekuritas terhadap pergerakan pasar, jadi fluktuasi dari return-return suatu sekuritas secara statistik mengikuti fluktuasi dari returnreturn pasar, sehingga karakteristik pasar akan menentukan nilai beta masing-masing sekuritas (Bambang dan Cahyani, 2009:67). Gambaran 
risiko sistematis pada 12 perusahaan food and beverage yang terdaftar di BEI tahun 2007-2011 adalah sebagai berikut : kenaikan rata-rata risiko sistematis pada tahun 2007 sebesar 7,959 (dalam satuan rasio), tahun 2009 sebesar 1,325 (dalam satuan rasio) tahun 2011 sebesar 0,351 (dalam satuan rasio), sedangkan penurunan risiko sistematis terjadi tahun 2008 sebesar 1,492 (dalam satuan rasio) tahun 2010 sebesar 11,013 (dalam satuan rasio). Perusahaanperusahaan yang tergolong perusahaan food and beverage risiko sistematis juga mengalami kenaikan serta penurunan tiap tahunnya.

Berdasarkan pengamatan terhadap 12 perusahaan food and beverage di BEI tahun 2007-2011 menunjukan fenomena yang menarik, karena sebagian besar variabel-variabel risiko sistematis, kinerja perusahaan, nilai perusahaan adalah berfluktuasi dan tidak menentu. Berbagai penelitian dengan menggunakan variabelvariabel risiko sistematis, kinerja perusahaan dan nilai perusahaan serta varabel sejenis telah banyak dilakukan sebelumnya, tetapi dari hasil penelitian yang dilakukan penulis melihat hasil yang cukup bervariatif antara penelitian satu dan penelitian lainnya. Bambang Sudiyatno (2010) menemukan bahwa risiko sistematis ( $\beta$ ) berpengaruh negatif dan signifikan terhadap kinerja perusahaan (ROA), Anuchitworawong (2000) menemukan bahwa sebelum masa krisis tahun 1996 dan sesudah masa krisis tahun 2000 business risk berpengaruh negatif dan signifikan terhadap ROA, selanjutnya sebelum masa krisis tahun 1996 dan sesudah masa krisis tahun 2000 financial risk berpengaruh negative tetapi tidak signifikan terhadap ROA. Uchida (2006), menemukan bahwa kinerja perusahaan (ROA) berpengaruh positif dan signifikan terhadap nilai perusahaan (Tobin's Q), namun Imam dan Irwansyah (2002), menemukan bahwa ROA tidak berpengaruh signifikan terhadap terhadap return saham, sesuai dengan konsep signaling theory ROA dapat digunakan sebagai signal informasi adanya aliran kas pada masa datang, oleh karena itu ROA akan berpengaruh positif signifikan terhadap return saham atau nilai perusahaan. Penelitian yang dilakukan oleh Ulupui (2007) menemukan hasil bahwa ROA berpengaruh positif signifikan terhadap return saham satu periode ke depan, oleh karena itu, ROA merupakan salah satu faktor yang berpengaruh terhadap nilai perusahaan, selanjutnya Carningsih (2009), dalam penelitiannya menemukan bahwa ROA justru berpengaruh negatif terhadap nilai perusahaan. Hasil yang berbeda diperoleh oleh Carlson dan Bathala (1997) menemukan bahwa ROA tidak berpengaruh terhadap nilai perusahaan. Shin \& Stulz (2000) menemukan bahwa Perubahan Systematic Risk berpengaruh positif dengan perubahan q, Villalonga \& Amit, 2004 menemukan Market risk (Beta) berpengaruh positif dan signifikan terhadap Nilai Perusahaan (Tobin's Q), hasil yang berbeda diperoleh Bambang Sudiyatno (2010) menemukan bahwa risiko sistematis berpengaruh positif tetapi tidak signifikan terhadap nilai perusahaan.

\section{KERANGKA PENELITIAN \& HIPOTESIS}

\subsection{Kerangka Pemikiran}

Perusahaan sebagai bagian dari suatu unit ekonomi akan menghadapi persoalan yang rumit apabila beroperasi pada tingkat risiko pasar yang tinggi, karena risiko pasar yang tinggi akan membuat kondisi bisnis menjadi tidak menentu atau dalam keadaan ketidakpastian. Penjualan perusahaan sulit diprediksikan secara tepat, sehingga perusahaan tidak dapat memprediksikan berapa laba yang akan diperolehnya Kondisi bisnis yang tidak menentu akan berpengaruh terhadap kinerja perusahaan, karena kinerja perusahaan sangat ditentukan oleh hasil penjualan pada setiap periodenya, sebaik apapun perusahaan dapat menghasilkan suatu produk namun jika tidak mampu menjual produk yang telah dihasilkannya, maka tidak akan ada artinya. Perusahaan akan banyak kehilangan kesempatan atau peluang untuk memperoleh laba, akibatnya terjadi sebaliknya 
karena perusahaan harus menanggung beban tetap yang tinggi sehingga dapat menurunkan kinerja perusahaan.

Risiko sistematis atau risiko pasar, seperti telah dijelaskan sebelumnya terjadi disebabkan karena perubahan-perubahan inflasi, tingkat suku bunga dan kurs. Risiko sistematis berpotensi untuk meningkatkan atau menurunkan kinerja perusahaan dan harga pasar saham, karena risiko sistematis sifatnya uncontrolable. Risiko sistematis menggambarkan perubahan yang lebih tinggi atau lebih rendah dari return saham individu terhadap return pasar, dan diukur menggunakan indikator beta saham, jadi besarnya beta saham menggambarkan risiko yang akan ditanggung oleh pemegang saham individu jika terjadi perubahan return pasar. Hubungan risiko sistematis dan kinerja perusahaan dapat dijelaskan oleh teori investasi. Berdasarkan teori investasi, meningkatnya inflasi, tingkat suku bunga dan kurs akan menyebabkan marginal cost of capital naik, naiknya marginal cost of capital akan menambah beban perusahaan, sehingga dapat menurunkan laba perusahaan, karena kenaikan inflasi, tingkat suku bunga dan kurs meningkatkan risiko sistematis, maka berarti meningkatnya risiko sistematis juga akan menurunkan laba perusahaan, dengan demikian sesuai dengan argumentasi teori investasi, maka kenaikan risiko sistematis akan menurunkan kinerja perusahaan. Berdasarkan pernyataan tersebut bisa disimpulkan bahwa risiko sistematis berpengaruh terhadap kinerja perusahaan, semakin tinggi risiko sistematis akan semakin rendah kinerja perusahaan.

Kinerja merupakan hal penting yang harus dicapai oleh setiap perusahaan dimanapun, karena kinerja merupakan cerminan dari kemampuan perusahaan dalam mengelola dan mengalokasikan sumber dayanya, informasi kinerja perusahaan, terutama profitabilitas, diperlukan untuk menilai perubahan potensial sumber daya ekonomi yang mungkin dikendalikan dimasa depan.
Hubungan kinerja perusahaan dan nilai perusahaan dapat dijelaskan oleh signaling theory. Berdasarkan beberapa literatur sebelumnya dapat disimpulkan bahwa signaling theory merupakan efek yang terjadi sebagai akibat dari pengumuman laporan keuangan yang ditangkap oleh para pengguna, khususnya para pelaku bursa, dengan adanya informasi keuangan tersebut akan menimbulkan efek yang ditangkap sebagai signal oleh para pelaku bursa sebagai peluang atau ancaman ke depan berkaitan dengan prospek investasi yang akan dilakukannya. Informasi keuangan sangat penting sekali bagi para pelaku bursa sebagai gambaran kinerja perusahaan, kinerja perusahaan bagi investor adalah sinyal untuk memutuskan apakah investasi akan dilakukan, kinerja perusahaan yang baik akan menarik minat investor untuk investasi dengan membeli saham perusahaan melalui pasar modal, semakin tinggi kinerja perusahaan, semakin banyak investor yang tertarik untuk membeli saham perusahaan, akibatnya harga saham naik, mengingat bahwa harga saham adalah representasi dari nilai perusahaan, maka naiknya harga saham berarti naik pula nilai perusahaan.

Nilai perusahaan secara langsung ataupun tidak langsung dipengaruhi juga oleh risiko sistematis, perusahaan dengan beta saham yang tinggi biasanya harga sahamnya sangat berfluktuasi, saham yang demikian tidak disukai oleh investor, akibatnya nilai transaksi dan volume perdagangannya akan menurun, menurunnya nilai transaksi dan volume perdagangan saham akan menurunkan indeks harga saham gabungannya. Penurunan indeks harga saham gabungan menggambarkan penurunan kinerja pasar modal, dan dengan menurunnya kinerja pasar modal, maka nilai perusahaan juga akan menurun.

Hubungan risiko sistematis dan nilai perusahaan dapat dijelaskan oleh teori CAPM. Berdasar teori CAPM, beta saham sebagai indikator dari risiko sistematis adalah satusatunya yang mempengaruhi return saham, beta 
saham mempunyai fungsi hubungan yang positif dengan return saham, jika beta saham naik, maka return saham juga naik, namun di dalam konsep penilaian saham, harga saham mempunyai fungsi hubungan yang terbalik atau negatif dengan return saham. Artinya jika harga saham naik, maka return saham akan turun, oleh karena itu beta saham mempunyai fungsi hubungan yang terbalik atau negatif dengan harga saham. Jadi, jika beta saham naik, maka harga saham akan turun, dan naiknya beta saham berarti naiknya risiko sistematis, sedangkan turunnya harga saham berarti turunnya nilai perusahaan. Berdasarkan pernyataan tersebut bisa disimpulkan bahwa risiko sistematis berpengaruh terhadap nilai perusahaan, semakin tinggi risiko sistematis akan semakin rendah nilai perusahaan.

Berdasarkan kerangka pemikiran tersebut, maka paradigma dalam penelitian ini digambarkan sebagai berikut :

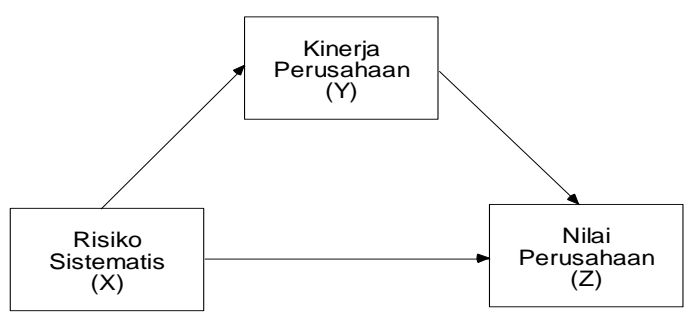

Gambar 1

Paradigma penelitian

\subsection{Hipotesis Penelitian}

Berdasarkan paradigma penelitian yang telah diuraikan di atas, maka dapat ditarik suatu hipotesis sebagai berikut :

1. Terdapat pengaruh risiko sistematis terhadap kinerja perusahaan

2. Terdapat pengaruh kinerja perusahaan terhadap nilai perusahaan

3. Terdapat pengaruh risiko sistematis terhadap nilai perusahaan

\section{METODE PENELITIAN}

Pemilihan lokasi penelitian di Bursa Efek Indonesia (BEI) melalui situs resminya www.idx.co.id. Sampel yang digunakan dalam penelitian ini dengan menggunakan teknik sampling purposive. Berdasarkan teknik sampling purposive maka diperoleh pertimbangan sebagai berikut :

1. Perusahaan yang selalu listed di Bursa Efek Indonesia selama tahun 2007-2011

2. Perusahaan yang secara rutin menyajikan dan mempublikasikan laporan keuangan secara berturut-turut tahun 2007-2011

3. Perusahaan yang secara berturut-turut termasuk dalam perusahaan food and beverage di Bursa Efek Indonesia tahun 2007-2011

Berdasarkan pertimbangan di atas maka diperoleh 12 perusahaan yang memenuhi criteria tersebut diantaranya : Akasha Wira International Tbk., Cahaya Kalbar Tbk., Davomas Abadi Tbk., Delta Djakarta Tbk., Indofood Sukses Makmur Tbk., Mayora Indah Tbk., Multi Bintang Indonesia Tbk., Prasidha Aneka Niaga Tbk., Sekar Laut Tbk., Siantar Top Tbk., Tiga Pilar Sejahtera Food Tbk., Ultrajaya Milk Industry \& Trading Co. Tbk.

Penelitian ini dilakukan dengan menggunakan metode deskriptif dan metode verifikatif, melalui metode deskriptif dapat diperoleh besarnya risiko sistematis (B), kinerja perusahaan (ROA), nilai perusahaan (Tobin's $Q$ ), selanjutnya dengan menggunakan metode verifikatif dapat mengetahui pengaruh atau bentuk hubungan kausal risiko sistematis (B), kinerja perusahaan (ROA), nilai perusahaan (Tobin's Q).

Risiko sistematis merupakan variabel eksogen yang diteliti (variabel independen), kinerja perusahaan merupakan variabel endogen yang diberlakukan sebagai variabel antara (intervening variable), nilai perusahaan merupakan variabel endogen yang diberlakukan sebagai variabel dependen. Variabilitas dalam total tingkat pengembalian sekuritas yang secara langsung berhubungan dengan gerakan secara 
keseluruhan di pasar umum atau ekonomi disebut risiko sistematis, indikatornya dengan beta saham dengan ukuran sebagai berikut :

$R_{i}=\alpha_{i}+\beta_{i} R_{m}+e_{i}$ (Jones, 2010:229)

Kinerja perusahaan bisa digambarkan melalui kondisi keuangan yang bisa diukur melalui rasio keuangan, indikator yang digunakan adalah Return On Asset (ROA) dengan ukuran sebagai berikut :

$$
R O A=\frac{\text { Laba bersih setelah pajak }}{\text { Total aktiva }}
$$

(Van Horne dan Wachowicz, 2005:224)

Nilai perusahaan sering didekomposisi menjadi nilai aset di tempat dan nilai peluang pertumbuhan, indikator yang digunakan Tobin's $Q$ dengan ukuran sebagai berikut :

$$
q=\frac{E+D}{A} \text { (Shin dan Stulz, 2000:3) }
$$

Teknik pengumpulan data mengunakan teknik dokumentasi, penulis mendapatkan data dan informasi yang berasal dari internet, jadi data yang digunakan adalah data sekunder. Data yang digunakan dalam penelitian ini adalah data sekunder yang dipublikasikan oleh Bursa Efek Indonesia (BEI) melalui situs resminya www.idx.co.id berupa Fact Book 2008-2012, selain itu data diperoleh dari www.finance.yahoo.com berupa data closing price saham bulanan dan www.duniainvestasi.com berupa data bulanan IHSG.

Metode analisis yang digunakan statistik deskriptif dan path analysis. Melalui statistik deskriptif maka analisis yang dilakukan adalah deskripsi nilai rata-rata, standar deviasi, nilai minimum, dan nilai maksimum dari setiap variabel (risiko sistematis, kinerja perusahaan, nilai perusahaan). Melalui analisis jalur ini dapat diketahui masing-masing variabel dan dapat digambar secara diagramatik struktur pengaruh dari variabel-variabel tersebut melalui diagram jalur (path diagram). Terdapat beberapa asumsi dalam path analisis seperti : model distribusi normal, multivariate outliers dan uji multikolinieritas, untuk model distribusi normal nilai or skewness dan kurtosis semuanya harus lebih kecil dari 2,58, untuk multivariate outliers nilai $d^{2}$ harus lebih kecil dari 16,266 (diperoleh dari perhitungan excel $(=\mathrm{CHIINV}(0.001,3)), 0.001$ menunjukan tingkat kesalahan dan angka 3 menunjukan jumlah variable yang diobservasi), untuk uji multikolinieritas apabila nilai CN > 1000 dan nilai determinant of sample covariance matrix $=0$, maka dalam data set sampel terdapat multikolinieritas. Berdasarkan kerangka pemikiran dan hipotesis penelitian yang telah diajukan sebelumnya, maka hubungan kausal antar variabel penelitian dapat digambarkan secara struktural dalam diagram jalur sebagai berikut:

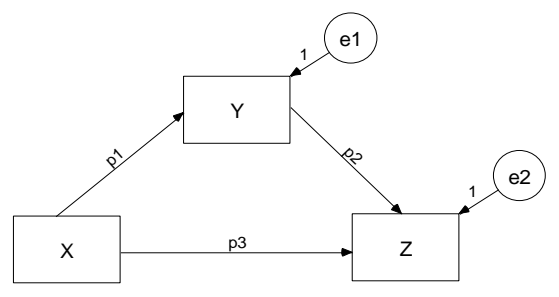

GAMBAR 2 MODEL STRUKTURAL

\section{HASIL DAN PEMBAHASAN}

\subsection{Hasil Penelitian}

Kenaikan rata-rata risiko sistematis ( $\beta$ ) pada tahun 2007 sebesar -1,155 (dalam satuan rasio) menjadi 0,763 (dalam satuan rasio) pada tahun 2008, tahun 2009 sebesar 0,494 (dalam satuan rasio) menjadi 1,910 (dalam satuan rasio) pada tahun 2010, sedangkan penurunan risiko sistematis ( $\beta$ ) terjadi tahun 2008 sebesar 0,763 (dalam satuan rasio) menjadi 0,494 pada tahun 2009 dan tahun 2010 sebesar 1,910 (dalam satuan rasio) menjadi 1,132 pada tahun 2011. Nilai beta agresif terjadi pada tahun 2010 sebesar 1,910 (dalam satuan rasio) dan tahun 2011 sebesar 1,132 (dalam satuan rasio), dikatakan nilai beta agresif karena nilai beta lebih besar dari satu, artinya saham tersebut mempunyai kepekaan yang tinggi terhadap kondisi pasar, saham-saham yang agresif sangat berisiko terhadap kondisi pasar yang lesu (bearish) dan akan memperoleh laba atau 
keuntungan yang besar pada saat pasar naik (bullish). Nilai beta defensif terjadi pada tahun 2007 sebesar -1,155 (dalam satuan rasio), tahun 2008 sebesar 0,763 (dalam satuan rasio) dan tahun 2009 sebesar 0,494 (dalam satuan rasio), dikatakan nilai beta defensif karena nilai beta lebih kecil dari satu, artinya saham tersebut kurang peka terhadap perubahan kondisi pasar.

Penurunan rata-rata kinerja perusahaan (ROA) terjadi pada tahun 2007 sebesar -1,152 \% menjadi $-1,398$ \% pada tahun 2008, sedangkan terjadi kenaikan rata-rata kinerja perusahaan (ROA) pada tahun 2008 sebesar -1,398 \% menjadi 8,880 \% pada tahun 2009, tahun 2009 sebesar $8,880 \%$ menjadi $9,161 \%$ pada tahun 2010, selanjutnya tahun 2010 sebesar 9,161 \% menjadi 10,912 \% pada tahun 2011. Nilai ratarata ROA positif terjadi pada tahun 2009 sebesar 8,880 \%, tahun 2010 sebesar 9,161 \%, tahun 2011 sebesar 10,912 \% , ROA yang positif disebabkan laba perusahaan dalam kondisi positif atau mengalami keuntungan, hal ini menunjukkan kemampuan dari modal yang diinvestasikan secara keseluruhan mampu untuk menghasilkan laba. Nilai rata-rata ROA negatif terjadi pada tahun 2007 sebesar $-1,152 \%$ dan pada tahun 2008 sebesar $-1,398 \%$, ROA yang negatif disebabkan laba perusahaan dalam kondisi negatif atau rugi, hal ini menunjukkan kemampuan dari modal yang diinvestasikan secara keseluruhan belum mampu untuk menghasilkan laba.

Penurunan rata-rata nilai perusahaan (Tobin's Q) terjadi pada tahun 2007 sebesar 1,522 (satuan rasio) menjadi 1,094 (satuan rasio) pada tahun 2008, dan tahun 2010 sebesar 2,019 (satuan rasio) menjadi 1,980 (satuan rasio) pada tahun 2011, sedangkan terjadi kenaikan rata-rata nilai perusahaan (Tobin's Q) pada tahun 2008 sebesar 1,094 (satuan rasio) menjadi 1,611 (satuan rasio) pada tahun 2009, selanjutnya tahun 2009 sebesar 1,611 (satuan rasio) menjadi 2,019 (satuan rasio) pada tahun 2010. Nilai ratarata nilai perusahaan tahun 2007-2011 memiliki rasio q atau Tobin's $Q$ diatas satu yang menunjukkan bahwa investasi dalam aktiva menghasilkan laba yang memberikan nilai yang lebih tinggi daripada pengeluaran investasi, hal ini akan merangsang investasi baru. Nilai rasio $\mathrm{q}$ atau tobin's $Q$ suatu perusahaan lebih dari 1 berarti pula nilai perusahaan lebih besar daripada nilai aktiva perusahaan yang tercatat, hal ini mengindikasikan bahwa terdapat beberapa aktiva perusahaan yang tidak terukur atau tercatat.

Jumlah perusahaan yang memenuhi kriteria adalah sebanyak 12 perusahaan, yang keseluruhannya merupakan perusahaan food and beverage selama tahun 2007 sampai dengan tahun 2011. Jumlah sampel yang diobservasi sebanyak 60, namun setelah dilakukan pengujian multivariate outliers, yaitu dengan mengeluarkan data outliers, maka jumlah sampel mengalami penurunan menjadi 51 observasi. Statistik deskriptif variabel terhadap 51 sampel yang di observasi dijelaskan sebagai berikut : distribusi data dengan varian tertinggi adalah $X$ (risiko sistematis) dengan standar deviasi sebesar 93,611\%, hal ini menggambarkan bahwa fluktuasi data risiko sistematis pada tiap-tiap perusahaan yang diobservasi relatif lebih tinggi dibandingkan dengan $Y$ (kinerja perusahaan) dan $Z$ (nilai perusahaan). Varian terendah adalah $Y$ (kinerja perusahaan) dengan standar deviasi sebesar 6,451\%.

Tingginya standar deviasi sebesar 93,611\% dari $X$ (risiko sistematis) menggambarkan bahwa $X$ (risiko sistematis) pada tiap-tiap perusahaan yang diobservasi memiliki perbedaan yang tinggi. Tingginya nilai standar deviasi dari $\mathrm{X}$ (risiko sistematis) pada tiap-tiap perusahaan yang diobservasi ini juga menunjukkan variabilitas nilai $X$ (risiko sistematis) dari tiap-tiap perusahaan cukup tinggi, sehingga jauh dari nilai mean-nya atau rata-rata industrinya ini menunjukkan bahwa titik data yang tersebar di berbagai macam nilai-nilai.

Varian dari Y (kinerja perusahaan) pada tiaptiap perusahaan yang diobservasi memiliki standar deviasi 6,451\% dan memiliki nilai mean 
6,069\%. Jika dibandingkan dengan $X$ (risiko sistematis) dan Z (nilai perusahaan), maka nilai standar deviasi $Y$ (kinerja perusahaan) relatif lebih rendah, dari nilai standar deviasi $X$ (risiko sistematis) dan Z (nilai perusahaan) pada tiaptiap perusahaan yang diobservasi, oleh karena itu nilai Y (kinerja perusahaan) dari tiap-tiap perusahaan yang diobservasi juga lebih mendekati nilai mean-nya jika dibandingkan dengan $X$ (risiko sistematis) dan $Z$ (nilai perusahaan). Kondisi ini menggambarkan bahwa nilai Y (kinerja perusahaan) yang diproksi dengan ROA dari perusahaan-perusahaan yang diobservasi mendekati rata-rata industrinya atau menunjukkan bahwa titik data cenderung sangat dekat dengan mean.

Terdapat beberapa asumsi dalam path analisis seperti : model distribusi normal, multivariate outliers dan uji multikolinieritas. Jumlah sampel yang diobservasi sebanyak 60, namun setelah dilakukan pengujian multivariate outliers, yaitu dengan mengeluarkan data outliers, maka jumlah sampel mengalami penurunan menjadi 51 observasi, disebabkan beberapa observasi nilai d2 masih diatas 16,266 maka observasi tersebut dikeluarkan dari data sampel. Selanjutnya dilakukan pengujian model distribusi normal dan pengujian multikolinieritas, sebelum dan sesudah trimming menunjukan data berdistribusi normal, nilai skew (0.904, 0.51, $1.159)$ kurtosis $(1.334,0.925,0.37)$ dan nilai c.r multivariate (1.842) lebih kecil dari 2,58, untuk pengujian multikolinieritas sebelum trimming nilai CN 344.225 masih lebih kecil dari 1000 dan nilai determinant of sample covariance matrix 0,001 masih lebih besar dari 0, selanjutnya setelah dilakukan trimming menunjukan nilai CN 344.225 masih lebih kecil dari 1000 dan nilai determinant of sample covariance matrix 0,0007 masih lebih besar dari jadi bisa disimpulkan dalam data sampel tidak terdapat problem multikolinieritas.

Besarnya pengaruh masing-masing variabel penyebab terhadap variabel akibat sebelum dilakukan trimming, besarnya pengaruh risiko sistematis $(X)$ terhadap kinerja perusahaan $(Y)$ adalah -0,203. Besarnya pengaruh kinerja perusahaan (Y) terhadap nilai perusahaan (Z) adalah 0,603. Besarnya pengaruh risiko sistematis $(X)$ terhadap nilai perusahaan (Z) adalah 0,243. Besarnya pengaruh masing-masing variabel penyebab terhadap variabel akibat setelah trimming, besarnya pengaruh kinerja perusahaan terhadap nilai perusahaan adalah 0,5854 (berdasar kategori Guilford, 0,40 - 0,70 pengaruhnya cukup kuat). Besarnya pengaruh risiko sistematis terhadap nilai perusahaan adalah 0,236 (berdasar kategori Guilford, 0,20 0,40 pengaruhnya lemah).

Besarnya pengaruh bersama risiko sistematis $(X)$ dan kinerja perusahaan ( $Y$ ) terhadap nilai perusahaan (Z) sebelum trimming adalah 0,36327. Artinya sebesar 36,33\% variasi yang terjadi pada nilai perusahaan dapat dijelaskan secara bersama oleh risiko sistematis dan kinerja perusahaan, sisanya sebesar $62,67 \%$ merupakan pengaruh variabel lain yang tidak terjelaskan model. Besar pengaruh bersama risiko sistematis $(X)$ terhadap kinerja perusahaan (Y) adalah 0,0411 atau sebesar 4,11\%. Artinya sebesar $4,11 \%$ variasi yang terjadi pada nilai perusahaan dapat dijelaskan secara bersama oleh risiko sistematis $(X)$ dan kinerja perusahaan (Y), sisanya 0,9589 atau sebesar 95,89\% merupakan pengaruh variabel lain yang tidak terjelaskan model. Besarnya pengaruh bersama risiko sistematis $(X)$ dan kinerja perusahaan $(Y)$ terhadap nilai perusahaan ( $Z$ ) setelah trimming adalah 0,3984. Artinya sebesar 39,84\% variasi yang terjadi pada nilai perusahaan dapat dijelaskan secara bersama oleh risiko sistematis dan kinerja perusahaan, sisanya sebesar 60,16\% merupakan pengaruh variabel lain yang tidak terjelaskan model.

Besarnya total pengaruh risiko sistematis $(X)$ terhadap kinerja perusahaan (Y) sebelum trimming sebesar -0,2026, risiko sistematis $(X)$ terhadap nilai perusahaan (Z) sebesar 0,1208 serta kinerja perusahaan $(Y)$ terhadap nilai perusahaan (Z) sebesar 0,6025. Besarnya total 
pengaruh langsung risiko sistematis $(X)$ terhadap kinerja perusahaan $(Y)$ sebelum trimming sebesar -0,2026, risiko sistematis $(X)$ terhadap nilai perusahaan (Z) sebesar 0,2429 serta kinerja perusahaan $(\mathrm{Y})$ terhadap nilai perusahaan ( $\mathrm{Z}$ ) sebesar 0,6025. Besarnya pengaruh tidak langsung risiko sistematis $(X)$ terhadap nilai perusahaan ( $\mathrm{Z}$ ) melalui kinerja perusahaan ( $\mathrm{Y}$ ) sebelum trimming sebesar 0,122067. Besarnya total pengaruh risiko sistematis $(X)$ terhadap nilai perusahaan (Z) setelah trimming sebesar 0,2360 (berdasar kategori Guilford, 0,20 - 0,40 pengaruhnya lemah) serta kinerja perusahaan terhadap nilai perusahaan sebesar 0,5854 (berdasar kategori Guilford, 0,40 - 0,70 pengaruhnya cukup kuat), sedangkan untuk besarnya pengaruh tidak langsung risiko sistematis $(\mathrm{X})$ terhadap nilai perusahaan $(\mathrm{Z})$ tidak ada, hasil ini menunjukkan bahwa risiko sistematis tidak ditangkap sebagai signal tidak langsung (indirect signaling), yaitu melalui kinerja perusahaan, melainkan ditangkap sebagai signal langsung (direct signaling) oleh para pelaku bursa.

Uji model fit sebelum trimming menunjukan nilai chi-square $=0,000$ dan $D F=0$ serta nilai CFI 1,000 lebih besar dari 0,9. Nilai P dengan RMSEA masih belum terlihat. Oleh karena itu ada satu koefisien jalur yang tidak signifikan yaitu koefisien jalur risiko sistematis terhadap kinerja perusahaan, karena itu model perlu diperbaiki, variabel $X$ dikeluarkan dari model. Uji model fit setelah trimming menunjukan nilai chi-square naik= 2,096 dan DF = 1 kurang dari 2 serta nilai CFI 0,949 lebih besar dari 0,9. Nilai $P=0,1477$ lebih besar dari 0,05, RMSEA =0,148 lebih besar dari 0,08. Nilai CFI dan P memenuhi kriteria uji model fit sedangkan RMSEA tidak, oleh karena itu melihat lebih jelasnya uji model fit dilakukan secara manual dengan statistik $Q$ dan W. Q menunjukan nilai 0,9761 , karena $Q$ lebih kecil dari 1, maka pengujian model fit dilakukan dengan statistic uji $W, W$ menunjukan nilai 1,20761 dengan derajat kebebasan (d) 1 dan tingkat kesalahan $(\alpha)$ sebesar 0,05 diperoleh tingkat signifikasi (nilai P-hitung) statistik W sebesar 0,2718, karena P-hiitung lebih besar dari 0,05, dengan demikian Ho tidak ditolak. Kesimpulannya adalah model fit dengan data. Artinya, model mampu mengestimasi matriks kovariansi atau matriks korelasi populasi yang tidak berbeda dengan matriks kovariansi atau matriks korelasi data sampel. Dengan kata lain, keberlakuan hasil estimasi parameter model pada sampel dapat diandalakan untuk diberlakukan terhadap populasi.

Hipotesis 1 menyatakan bahwa terdapat pengaruh risiko sistematis $(X)$ terhadap kinerja perusahaan $(Y)$. Hasil pengujian secara statistik risiko sistematis $(X)$ tidak berpengaruh terhadap kinerja perusahaan $(\mathrm{Y})$ pada level significant $5 \%$ $($ P-hitung $=0,143$ (tabel 4.11) > 0,05). Jadi, berdasarkan pengujian secara statistik seperti tersebut, disimpulkan bahwa HO diterima, adanya variabel yang hipotesisnya ditolak, maka dalam analisis jalur variabel tersebut dikeluarkan dari model (trimming), sebagai akibat dilakukannya trimming, dihasilkan model kedua, yaitu model baru yang menghilangkan pengaruh risiko sistematis terhadap kinerja perusahaan. Hasil penelitian ini memberikan pemahaman bahwa selama periode pengamatan tahun 20072011, return on asset (ROA) perusahaan food and beverage yang listed di BEI tidak dipengaruhi beta sahamnya.

Hipotesis 2 menyatakan bahwa terdapat pengaruh kinerja perusahaan $(\mathrm{Y})$ terhadap nilai perusahaan (Z). Hasil pengujian secara statistik kinerja perusahaan berpengaruh terhadap nilai perusahaan, tabel 4.18 menunjukan nilai $\mathrm{P}=* * *$ (sangat signifikan). Jadi, berdasarkan pengujian secara statistik seperti tersebut, disimpulkan bahwa HO ditolak. Hasil penelitian ini memberikan pemahaman bahwa naiknya kinerja perusahaan ditangkap langsung sebagai signal positif bagi para pelaku bursa, sehingga harga saham naik. Kenaikan kinerja perusahaan menunjukan keberhasilan perusahaan mengimplementasikan kebijakannya, keberhasilan ini mendorong harga saham 
perusahaan naik, karena para pelaku bursa berkeyakinan akan mendapatkan return yang tinggi dari investasinya.

Hipotesis 3 menyatakan bahwa terdapat pengaruh risiko sistematis $(X)$ terhadap nilai perusahaan (Z). Hasil pengujian secara statistik risiko sistematis berpengaruh terhadap nilai perusahaan pada level significant 5\% (P-hitung = 0,0315 (tabel 4.18) < 0,05). Jadi, berdasarkan pengujian secara statistik seperti tersebut, disimpulkan bahwa HO ditolak. Makna dari hasil pengujian tersebut adalah bahwa selama periode pengamatan 2007-2011, beta saham perusahaan food and beverage yang listed di BEI mempengaruhi nilai perusahaan.

\subsection{Pembahasan}

Risiko sistematis tidak berpengaruh terhadap kinerja perusahaan, kondisi ini menggambarkan bahwa kinerja perusahaan sebagai hasil implementasi dari kebijakan perusahaan besar kecilnya tidak dipengaruhi oleh volatilitas kondisi pasar, kondisi pasar yang relatif stabil tidak membuat kinerja perusahaan meningkat, pada saat kondisi pasar tidak stabil atau kondisi pasar cepat berubah juga tidak menurunkan kinerja perusahaan. Jadi, pada saat kondisi pasar yang tidak stabil dan cepat berubah tidak akan mengakibatkan risiko pasar meningkat atau menurun. Tidak terdapat pengaruh risiko sistematis terhadap kinerja perusahaan memberikan pemahaman bahwa kinerja perusahaan tidak dipengaruhi faktor eksternal perusahaan tetapi faktor internal perusahaan bisa berupa kebijakan investasi, kebijakan dividen, kebijakan pendanaan. Penelitian ini mendukung penelitian Anuchitworawong (2000) yang meneliti pengaruh risiko terhadap kinerja perusahaan menemukan bahwa sebelum masa krisis tahun 1996 dan sesudah masa krisis tahun 2000 risk tidak berpengaruh terhadap ROA, tetapi tidak mendukung penelitian yang dilakukan oleh Bambang Sudiyatno (2010) menemukan bahwa risiko sistematis $(\beta)$ berpengaruh terhadap kinerja perusahaan (ROA).
Kinerja perusahaan berpengaruh terhadap nilai perusahaan, para pelaku bursa saham akan selalu mengharapkan adanya return dari investasinya, baik yang berupa dividend yield maupun capital gain dari kepemilikan saham perusahaan. Return ini hanya akan diperoleh jika perusahaan menghasilkan laba pada setiap kegiatan operasinya. Oleh karena itu, return on assets (ROA) sebagai indikator dari kinerja perusahaan akan dipandang sebagai signal positif dari adanya ekspektasi return pada perusahaan tersebut. Hasil ini menunjukkan bahwa return on assets (ROA) ditangkap sebagai signal langsung (direct signaling) adanya expected return dari investasinya, sehingga semakin tinggi return on asset (ROA), semakin besar harapan investor untuk mendapatkan laba dari investasinya, oleh karena itu kebijakan manajerial lebih diarahkan pada peningkatan kinerja perusahaan khusunya kinerja keuangan melalui peningkatan return on assets (ROA) atau kemampuan menghasilkan laba dari seluruh aktiva yang dimiliki, peningkatan ini akan mengakibatkan investor saham tertarik dan membeli saham perusahaan. Penelitian ini mendukung signaling theory, signaling theory merupakan efek yang terjadi sebagai akibat dari pengumuman laporan keuangan yang ditangkap oleh para pengguna, khususnya para pelaku bursa, dengan adanya informasi keuangan tersebut akan menimbulkan efek yang ditangkap sebagai signal oleh para pelaku bursa sebagai peluang atau ancaman ke depan berkaitan dengan prospek investasi yang akan dilakukannya. Informasi keuangan sangat penting sekali bagi para pelaku bursa sebagai gambaran kinerja perusahaan, kinerja perusahaan bagi investor adalah sinyal untuk memutuskan apakah investasi akan dilakukan, kinerja perusahaan yang baik akan menarik minat investor untuk investasi dengan membeli saham perusahaan melalui pasar modal, semakin tinggi kinerja perusahaan, semakin banyak investor yang tertarik untuk membeli saham perusahaan, akibatnya harga saham naik, mengingat bahwa harga saham adalah 
representasi dari nilai perusahaan, maka naiknya harga saham berarti naik pula nilai perusahaan. Penelitian ini mendukung penelitian sebelumnya yang dilakukan Uchida (2006) menemukan bahwa kinerja perusahaan (ROA) berpengaruh terhadap nilai perusahaan (Tobin's Q) dan penelitian yang dilakukan Ulupui (2007) menemukan hasil bahwa ROA berpengaruh terhadap return saham satu periode ke depan, oleh karena itu, ROA merupakan salah satu faktor yang berpengaruh terhadap nilai perusahaan, tetapi tidak mendukung penelitian yang dilakukan oleh Imam dan Irwansyah (2002) menemukan bahwa ROA tidak berpengaruh terhadap terhadap return saham, Carningsih (2009) dalam penelitiannya menemukan bahwa ROA justru berpengaruh terhadap nilai perusahaan, Carlson dan Bathala (1997) menemukan bahwa ROA tidak berpengaruh terhadap nilai perusahaan.

Risiko sistematis berpengaruh terhadap nilai perusahaan, makna dari hasil tersebut adalah bahwa harga saham sebagai indikator dari nilai perusahaan dipengaruhi oleh risiko sistematis. Beta saham sebagai indikator dari risiko sistematis menunjukkan tingkat volatilitas perubahan return pasar (IHSG) terhadap return saham. Oleh karena itu, semakin tinggi tingkat volatilitas perubahan return pasar (IHSG) terhadap return saham, semakin tinggi risiko perusahaan. Risiko sistematis memiliki pengaruh terhadap nilai perusahaan, kebijakan manajerial dalam konteks ini lebih diarahkan pada upaya meningkatkan kepercayaan masyarakat terhadap perusahaan dengan cara mempertahankan stabilitas laba yang berkelanjutan agar harga pasar sahamnya tetap stabil. Stabilitas harga saham penting, karena stabilitas ini akan menentukan indeks harga saham secara keseluruhan, dengan harga pasar saham yang stabil, maka indeks harga saham gabungan juga relatif stabil, dan hal ini akan dapat menurunkan koefisien beta saham perusahaan terhadap beta pasarnya, mengingat bahwa pengukur risiko sistematis adalah koefisien beta saham, maka dengan beta saham yang rendah menujukkan risiko sistematis juga rendah, kondisi ini akan menarik para pelaku bursa, karena dengan risiko sistematis yang rendah, maka stabilitas harga saham perusahaan food and beverage akan lebih terjaga. Penelitian ini mendukung penelitian sebelumnya yang dilakukan Shin \& Stulz (2000) yang menemukan bahwa perubahan Systematic Risk berpengaruh terhadap q, penelitian yang dilakukan Villalonga \& Amit (2004) menemukan Market risk (Beta) berpengaruh terhadap Nilai Perusahaan (Tobin's Q), tetapi tidak mendukung penelitian yang dilakukan oleh Bambang Sudiyatno (2010) menemukan bahwa risiko sistematis tidak berpengaruh terhadap nilai perusahaan. Berdasarkan uraian dari temuantemuan tersebut di atas, dapat disimpulkan bahwa penelitian ini memberikan kontribusi dengan mendukung beberapa temuan dari penelitian sebelumnya, namun demikian, hasil penelitian ini juga masih menyisakan beberapa perbedaan-perbedaan yang nantinya dapat ditindak lanjuti pada penelitian-penelitian berikutnya.

\section{KESIMPULAN}

Berdasarkan hasil analisis data dan pembahasan yang telah dijelaskan pada Bab terdahulu, maka dapat ditarik kesimpulan dari penelitian ini sebagai berikut :

1. Gambaran risiko sistematis pada perusahaan food and beverage di Bursa Efek Indonesia tahun 2007-2011, rata-trata beta agresif terjadi pada tahun 2010 dan tahun 2011, sedangkan rata-rata beta defensif terjadi pada tahun 2007, tahun 2008 dan tahun 2009.

2. Gambaran kinerja perusahaan pada perusahaan food and beverage di Bursa Efek Indonesia tahun 2007-2011, rata-rata return on assets (ROA) positif terjadi pada tahun 2009, tahun 2010 dan tahun 2011, sedangkan rata-rata return on assets (ROA) 
negatif terjadi pada tahun 2007 dan tahun 2008.

3. Gambaran kinerja perusahaan pada perusahaan food and beverage di Bursa Efek Indonesia tahun 2007-2011, rata-rata nilai perusahaan tahun 2007-2011 memiliki rasio $q$ atau Tobin's $Q$ diatas satu.

4. Tidak terdapat pengaruh risiko sistematis terhadap kinerja perusahaan. Hasil penelitian ini memberikan pemahaman bahwa kinerja perusahaan sebagai hasil implementasi dari kebijakan perusahaan besar kecilnya tidak dipengaruhi oleh volatilitas kondisi pasar, kondisi pasar yang relatif stabil tidak membuat kinerja perusahaan meningkat, pada saat kondisi pasar tidak stabil atau kondisi pasar cepat berubah juga tidak menurunkan kinerja perusahaan. Jadi, kinerja perusahaan tidak dipengaruhi faktor eksternal perusahaan tetapi faktor internal perusahaan. Jadi, selama periode pengamatan tahun 20072011, return on asset (ROA) perusahaan food and beverage yang listed di BEI tidak dipengaruhi beta sahamnya.

5. Terdapat pengaruh kinerja perusahaan terhadap nilai perusahaan. Hasil penelitian ini memberikan pemahaman empirik pada manajemen, bahwa selama tahun 20072011 (khususnya pada perusahaan food and beverage), para pelaku bursa di BEI menggunakan informasi laporan laba kinerja perusahaan sebagai value basic dalam mengambil keputusan investasinya. Penggunaan value basic oleh investor ditunjukan oleh respon positif meningkatnya harga pasar saham di BEl, sehingga dengan naiknya harga pasar saham, maka nilai perusahaan meningkat.

6. Terdapat pengaruh risiko sistematis terhadap nilai perusahaan. Hasil penelitian ini memberikan pemahaman risiko sistematis terhadap nilai perusahaan disebabkan karena ada signal yang ditangkap oleh para pelaku bursa terhadap risiko sistematis, sehingga selama periode pengamatan 2007-2011, beta saham perusahaan food and beverage yang listed di BEI mempengaruhi nilai perusahaan.

\section{REKOMENDASI}

1. Bagi investor yang akan menanamkan investasinya pada perusahaan food and beverage di BEI sebaiknya harus benarbenar teliti dalam menganalisa saham guna memperoleh informasi yang akurat baik return, risiko, dan kemungkinan lain yang melekat pada saham di mana ia berinvestasi, sehingga nantinya diharapkan investor akan mendapatkan keuntungan sesuai dengan yang diharapkan. Analisa dapat dilakukan dengan menggunakan beberapa alat analisa yang dapat dipakai seperti menggunakan risiko sistematis yang diukur beta dan kinerja perusahaan yang diukur ROA yang terbukti mempengaruhi nilai perusahaan food and beverage di BEI.

2. Peneliti menyadari bahwa penelitian ini masih jauh dari sempurna, untuk itu peneliti memberikan saran untuk penelitian selanjutnya sebaiknya periode penelitian yang digunakan ditambah sehingga menghasilkan informasi yang lebih mendukung, jumlah sampel yang digunakan dapat ditambah dan dapat diperluas ke beberapa sektor perusahaan, selain itu jumlah variabel yang digunakan juga diperbanyak sehingga nantinya diharapkan kesimpulan yang diperoleh lebih sempurna, misalnya menambah variabel kebijakan perusahaan (insentif manajer, capital expenditure, leverage keuangan) dan variabel-variabel lainnya yang dapat mempengaruhi kinerja perusahaan maupun nilai perusahaan. 


\section{DAFTAR PUSTAKA}

Akroman. (2009). Pengaruh Rasio Keuangan (ROA dan ROE) Dan EVA Terhadap Harga Saham Pada Perusahaan Yang Terdaftar di JII Periode 2004-2006. Skripsi Universitas Islam Negeri Sunan Kalijaga Yogyakarta.

Anuchitworawong, Chaiyasit. (2004). Ownershipbased Incentives, Internal Corporate Risk and Firm Performance. Available at : http://hermes

ir.lib.hitu.ac.jp/rs/bitstream/10086/13931/1

/wp2004-17a.pdf

Bambang Sudiyatno. (2010). Peran Kinerja Keuangan Dalam Menentukan Faktor Fundamental Makroekonomi, Risiko Sistematis, Kebijakan Perusahaan Terhadap Nilai Perusahaan. Disertasi Doktor IImu Ekonomi Universitas Dipenogoro Semarang.

Bambang Sudiyatno dan Cahyani Nuswandhari. (2009). Peran Beberapa Indikator Ekonomi dalam Mempengaruhi Risiko Sistematis Perusahaan Manufaktur di Bursa Efek Indonesia. Jurnal Dinamika Keuangan dan Perbankan, Vol. 1 No. 2, Hal. 66 - 81. Semarang.

Carningsih. (2009). Pengaruh Good Corporate Governance Terhadap Hubungan Antara Kinerja Keuangan Dengan Nilai Perusahaan Studi Kasus Pada Perusahaan Property dan Real Estate Yang terdaftar di Bursa Efek Indonesia. Skripsi Universitas Gunadarma Jakarta.

Carlson, Steven and Bathala Chenchuramaiah. (1997). Ownership Differences and Firm's Income Smoothing Behaviour. Journal of Business and Accounting 24 (2). March, page 179-196.

Dodd, J.L, and Chen, S. (1996). EVA: A New Panacea?. Available at : http://www.theziels.org/BandE/bande42/42 n4/eva.htm
Imam Ghozali dan Irwansyah. (2002). Analisis Pengaruh Kinerja Keuangan Perusahaan dengan alat ukur EVA, MVA dan ROA terhadap Return Saham pada Perusahaan Manufaktur di BEJ. Jurnal Penelitian Akuntansi-Bisnis dan Manajemen. Vol. 9, No. 1, Hal. 18-33.

Jogiyanto Hartono. (2003). Teori Portofolio dan Analisis Investasi. Edisi 3. Yogyakarta : BPFE Fakultas Ekonomi Universitas Gadjah Mada.

Jones, Charles P. (2010). Investments Analysis and Management, Eleventh Edition. United States of America : Quebecor World Versaliles.

Shin, H-H and Stulz, R.M. (2000). Firm Value, Risk, and Growth Opportunities. Available at

http://papers.ssrn.com/sol3/papers.cfm?ab stract_id $=234344$

Suad Husnan dan Enny Pudjiastuti. (2004). Dasar Dasar Manajemen Keuangan. Yogyakarta : Amp YKPN

Uchida. (2006). Agency Cost of Debt and the Relationship Between Firm Performance and Managerial Ownership: Evidence from Japan. Tersedia : http://www.kitakyuu.ac.jp/economy_new/research/files/Uchid a5.pdf

Ulupui, I. G. K. A. (2007). Analisis Pengaruh Rasio Likuiditas, Leverage, Aktivitas, dan Profitabilitas terhadap Return saham (Studi pada Perusahaan Makanan dan Minuman dengan Kategori Industri Barang Konsumsi di Bursa Efek Jakarta). Jurnal Akuntansi dan Bisnis, Januari, hal. $88-102$.

Van Horne, James and John. M. Wachowicz. (2005). Fundamental of Financial Management (Prinsip-prinsip Manajemen Keuangan). Edisi 12, Buku 1. Edisi Indonesia. Penerjemah : Dewi Fitriasari dan Deny Arnos Kwary. Jakarta : Salemba Empat. 
Villalonga, Belen and Amit, R. (2004). How Do Family Ownership, Management, and Control Affect Firm Value?. Tersedia : http://www.people.hbs.edu/bvillalonga/Vill alongaAmitJFE2006.pdf

Website :

http://bps.go.id

http://finance.yahoo.com

http://idx.co.id 